\title{
Impacts of honeybee density on crop yield: A meta-analysis
}

\author{
Orianne Rollin (i) | Lucas A. Garibaldi
}

Instituto de Investigaciones en Recursos Naturales, Agroecologia y Desarrollo Rural (IRNAD), Sede Andina, Universidad Nacional de Río Negro (UNRN) y Consejo Nacional de Investigaciones Científicas y Técnicas (CONICET), San Carlos de Bariloche, Río Negro, Argentina

Correspondence

Orianne Rollin

Email: orianne.rollin@gmail.com

\section{Funding information}

Agencia Nacional de Promoción Científica y Tecnológica, Grant/Award Number: 20131079; Consejo Nacional de Investigaciones Científicas y Técnicas, Grant/Award Number: 298/14 and 8383/13; Universidad Nacional de Río Negro, Grant/Award Number: 40-B-399 and 40-B-567

Handling Editor: Tim Diekötter

\section{Abstract}

1. There is increasing recognition that pollination deficits are limiting crop yields world-wide. However, management strategies for optimal insect pollination are still unclear for most crops. Current management focuses on providing high densities of honeybees, but recommended densities are highly variable, even within single crops and cultivars.

2. We performed an extensive literature search to record honeybee densities (colony density and/or flower visitation rates) and crop productivity (fruit set, seed set, fruit weight and/or yield). Effect sizes were represented as the difference in crop productivity between the two most extreme levels of honeybee densities.

3. Out of 795 reviewed studies, only 22 analysed the effect of at least two levels of honeybee densities on crop productivity (reporting 60 resulting effect sizes in total). Moreover, few recommendations for crop pollination management are based on results from controlled experimental designs, and with comparable methodology.

4. We found that both colony density and visitation rates increased all the productivity variables. However, effects were nonlinear for visitation rates, suggesting that there is an optimum (mean of 8-10 visits per flower) beyond which more honeybees are not beneficial (and can even be detrimental) for crop productivity.

5. Effect sizes for visitation rates were greater than that for colony densities, suggesting that visitation rates are a more direct measure of the pollination process. Data on the relation between colony density and visitation rates are lacking. Interestingly, effect sizes for visitation rates were greater for crops with separate sexes than those with hermaphroditic flowers; therefore, the benefits of honeybee pollination vary according to the crop biology.

6. Synthesis and applications. Current practices for crop pollination assume that more honeybees are always better for crop yield, even if the effect of this management on crop production still unclear. In contrast, our analyses suggest that there is an optimum for honeybee densities. Despite the importance of honeybees and pollinator-dependent crops world-wide, there is a lack of studies designed for finding such an optimal level of crop pollination. Our analyses further suggest that visitation rates could be used as a proxy to guide management recommendations such as colony density and spatial arrangement. 
KEYWORDS

crop yield, fruit set, fruit weight, honeybee colony density, pollination, seed set, visitation rate

\section{1 | INTRODUCTION}

The European honeybee (Apis mellifera L.) is the foremost species used for crop pollination world-wide, both in open pollination (fields, orchards) and enclosed systems (Garibaldi, Requier, Rollin, \& Andersson, 2017). Honeybees have a large area of native distribution, generalist feeding behaviour (visit a large range of plants), high adaptability to a broad range of climatic conditions and high tolerance to human management (Delaplane \& Mayer, 2000; Michener, 2007). To maximize crop productivity, the goal is usually to saturate crop flowers with honeybee foragers provided by large numbers of colonies brought at the onset of flowering of the target crop (James $\&$ Pitts-Singer, 2008).
Currently, there is no consensus on the optimal colony density to maximize crop yield, and recommendations are highly variable, even within the same crops and cultivars. Reference books on the topic (Delaplane \& Mayer, 2000; Free, 1993) and certain other references (Cunningham, Fournier, Neave, \& Le Feuvre, 2016; Department of Agriculture and Food, 2006; Gaines-Day, 2013; Howlett, Nelson, Pattemore, \& Gee, 2015; Isaacs \& Kirk, 2010; Le duc \& Turcotte, 2004; Sheffield, Ngo, \& Azzu, 2016) list a very large range of colony densities for various crops (Figure 1). For example, recommended honeybee densities for strawberries range from 2 to 25 colonies/ ha with values originating from several continents and no indication of pollination success. A similar range of variability is observed for blueberry pollination (1-25 colonies/ha). This range can be even
FIGURE 1 Examples of recommended numbers of honeybee colonies for crop pollination world-wide (points are the mean values, while black lines show the range of recommended values). Plants with imperfect flowers are identified by * for monoecious plants or ** for dioecious plants. Numbers on the right side correspond to the following references. 1: Delaplane and Mayer (2000); 2 : Cunningham et al. (2016); 3: Sheffield et al. (2016); 4: Isaacs and Kirk (2010); 5: Le duc and Turcotte (2004); 6: Gaines-Day (2013); 7: Department of Agriculture and Food (2006); 8: Howlett et al. (2015)

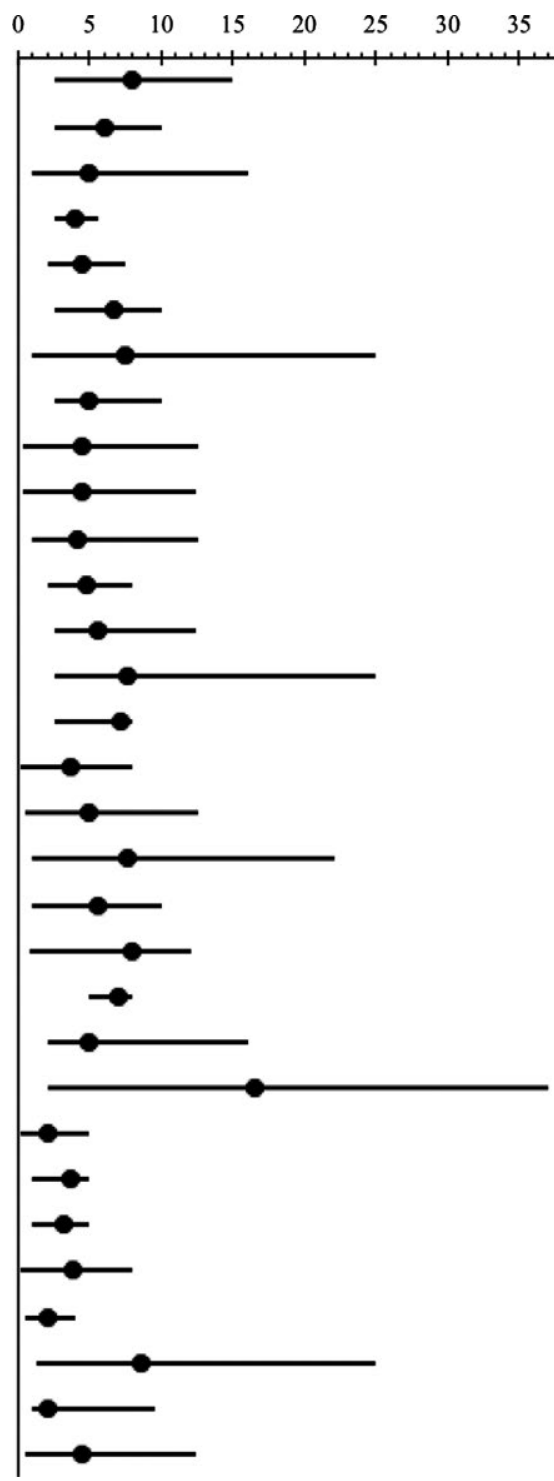

Alfalfa 1

Almond $\quad 1 ; 2$

Apple $\quad 1 ; 3$

Asparagus 1

Avocado 1

Blackberry 1

Blueberry $1 ; 4$

Cabbage 1

Cantaloupe * $^{*} 1$

Carrot seed 1

Cherry 1

Clover - Alsike (Trifolium hybridum) 1

Clover - Crimson (Trifolium incarnatum) 1

Clover - red (Trifolium pratense)

Clover - Sweet clover (Melilotus officinalis) 1

Clover - White (Trifolium repens) 1

Cotton 1

Cranberry $\quad 1 ; 5 ; 6$

Cucumber * 1

Kiwi ** 1

Macadamia $\quad 7 ; 8$

Oilseed rape 1

Onion 1

Peach 1

Pear 1

Plum/Prune 1

Pumpkin * 1

Raspberry 1

Strawberry 1

Sunflower ** 1

Watermelon * 1 
more extreme, such as for onion cropping systems (from 2 to 37 colonies/ha). Even traditional crops with high economic value at the global scale like apples have unclear recommendations (ranging from 1 to 16 colonies/ha). Moreover, the recommended mean density of colonies can double between two species of the same genus, such as for sour cherry and sweet cherry ( 2.5 and 4.2 colonies/ha respectively) or for clovers (3.7 and 7.7 colonies/ha for respectively for Trifolium repens and T. pratens) (Delaplane \& Mayer, 2000). Thus, pollination is a multifaceted component of crop productivity and not easily reduced to applied recommendations. Furthermore, the recommended density of honeybees is difficult to synthesize because the literature is often scarce or incongruent, with strong fluctuations according to the crops, cultivars and spatial context.

It is generally assumed that more colonies increase pollination and crop productivity, but effects might be nonlinear (e.g. asymptote or sigmoidal curves) (Delaplane \& Mayer, 2000; Morris, Vázquez, \& Chacoff, 2010; Steffan-Dewenter, 2003). Management strategy by saturation can result in an unusually high density of honeybees and may trigger drastic changes in local assemblages of wild insects (Mallinger, Gaines-Day, \& Gratton, 2017). Such changes in species composition could increase interaction costs and reduce plant reproductive success and crop productivity (quantity and/or quality) (Aizen et al., 2014; Hargreaves, Harder, \& Johnson, 2009, 2010; Morris et al., 2010). Indeed, wild pollinators are a vital part of our crop systems (Garibaldi et al., 2013), and can improve pollination efficiency of honeybees (e.g. Brittain, Williams, Kremen, \& Klein, 2013). However, wild bees are also less abundant in large fields and show lower visitation rates and lower fidelity to individual plant species over time (Burkle, Marlin, \& Knight, 2013), perhaps due to competition for resources with honeybees (Isaacs \& Kirk, 2010). In this context, it appears that combining controlled pollination services that use honeybee colonies with wild bee conservation strategies, by taking into account the levels of wild pollinators in the landscape, is important for ensuring stable pollination and sustainable crop yield. Other mechanisms by which high densities of honeybees can be detrimental to crop productivity include: when insect pollinators damage flowers during their visits or when a surplus of pollen deposition leads to stagnation of growing pollen tubes, as demonstrated both under experimental and natural conditions (Morris et al., 2010; Sáez, Morales, Ramos, \& Aizen, 2014; Young, 1988; Young \& Young, 1992). Therefore, increasing honeybee densities, through the introduction of a large quantity of colonies, does not necessarily ensure better crop productivity.

Furthermore, the relationship between the density of honeybee colonies and the resulting forager visitation rate to crop flowers remains largely unknown, and could even be nonlinear. First, population dynamics and by consequence the forager quantity in one given colony depends on various biotic and abiotic factors, such as the quantity and quality of feeding resources in the landscape, colony reserves, viruses and pathogens (Dennis \& Kemp, 2016; Goulson, Nicholls, Botías, \& Rotheray, 2015). Second, some mechanisms such as spillover or resource selection can modify the spatial distribution of honeybee foragers in the landscape (Holzschuh et al., 2016; Rollin et al., 2013; Tscharntke et al., 2012), thereby altering the response to the increase in colony density. For example, if the foragers have stronger preferences for a floral resource other than the targeted crop in the landscape, we can suppose that the increase of colony density could have a lower effect than predicted on the targeted crop pollination and productivity (Blitzer et al., 2012). Third, a honeybee colony is not a standardized unit; colonies can vary around the world according to the number of bees, if it is a split colony or not, the stage in the colony dynamics (e.g. spring or summer; Russell, Barron, \& Harris, 2013), and the type of hive (Crane, 1999) with different structures (horizontal vs. vertical), size of the hive body and number of frames in the hive body (Crane, 1999). Moreover, pathogens and viruses can significantly change the colony dynamic and strength and reduce the number of workers compared to a healthy population of the same type of hive (vanEngelsdorp \& Meixner, 2010). Consequently, it becomes important to evaluate the effect of honeybee density on crop productivity (quality and quantity) of the major cropping systems around the world, through different ecological measures such as colony density and visitation rate, to permit a sustainable management of pollination services.

In this study, we examine the global effects of honeybee densities on crop productivity using a meta-analysis approach. Specifically, we asked: What is the effect of honeybee densities (as represented by colony density or flower visitation rates) on crop productivity (fruit set, seed set, fruit weight and/or yield)? At which honeybee density do benefits for crop productivity level off? How do these benefits change for contrasting crops world-wide?

\section{2 | MATERIALS AND METHODS}

\section{1 | Study selection}

For the meta-analysis, an extensive literature search was performed on the Web of Science, last updated in April 2017, using the search string "[honeybee* OR honeybee* OR Apis mellifera] AND [crop productivity* OR crop yield* OR yield gain* OR fruit set* OR fruit quality OR seed set* OR tube growth OR pollen deposit* OR visitation rate*]." As a result, a total of 793 studies were identified. Another literature search was performed using Google Scholar to access grey literature such as conference papers, reports, book chapters, but only two additional studies were found suitable. Abstracts and full-texts of these 795 studies were reviewed for relevance, using the following criteria:

1. Is it an empirical study of the effect of honeybee density on crop productivity?

2. Does it contain original results?

3. Does it contrast at least two levels of honeybee densities?

4. Does it measure any of the following variables: colony density, visits or abundance per flower or the number of honeybees per plant?

5. Does it report honeybee impacts in terms of one or more of the following crop productivity measures: fruit set (fruit/flower), fruit weight (g/fruit), fruit length $(\mathrm{cm})$, seed set (seeds/fruit) or yield (kg/plant or kg/hectare)? 
Studies selected in the Web of Science were identified by our keywords, but many used these keywords only to explain the context or discussion of the study, without analysing processes of honeybee pollination and/or crop productivity. Consequently, they were excluded from the meta-analysis. In addition, the measures of crop productivity needed to be based on pollination by honeybees. Moreover, honeybee densities had to be randomly assigned to experimental units (plots) in a controlled (manipulated) experiment such that differences among plots could be attributed to the experimental error and avoid biasing the results. Finally, some of the studies selected in the previous step had a specific methodology that did not permit us to combine and analyse data with the other ones (e.g. total number of foragers without surface unit, e.g. hectare or metre squared), and they were not included in the meta-analysis database, which covered, at this stage, 32 remaining studies, of which only 22 studies were included in the meta-analysis (see below).

\subsection{Data collection and effect sizes}

For each study, we recorded the mean and SD for each crop productivity variable (i.e. response variables). Authors were contacted if the study design met our criteria but the data were not reported in a format suitable for our analysis. When a selected publication only presented their results graphically, we used Plot Digitizer (http:// plotdigitizer.sourceforge.net) to obtain means and, if reported, sample variances (Thorn et al., 2017).

Each effect size represents the difference between two levels of honeybee densities (as measured by colony densities or flower visitation rates) on the crop productivity variable for one crop. When a study provided more than two levels of honeybee densities (which occurred in nine of the selected studies), we chose the two most extreme levels of these densities. The effect sizes were estimated separately for each year (Table 1). Indeed, most of the studies provided data for only 1 year (13 studies; see Table 1 ), thus mixedeffects models could not be applied (i.e. most random effects will be estimated with only one data point) and any possible influence of multiple years is small. Moreover, in some studies, different plots were sampled in different years. For comparing data across studies we calculated the effect size of the various response variables as the response ratios (R) analysed on a log unit (InR) (Borenstein, Hedges, Higgins, \& Rothstein, 2009). A positive InR value indicates higher crop productivity when honeybee densities increase, whereas a negative value indicates a decrease in crop productivity. A null value indicates no effect of the addition of honeybees on crop productivity.

\section{3 | Data analyses}

We could estimate the effect sizes for 32 studies but only 22 studies were included in the quantitative analyses because there was not enough replication (at least five effect sizes) for the following metrics: number of honeybees per 100 flowers, number of colonies per field, visitation rate per tree, number of honeybee foragers introduced in the field and number of honeybee visits per minute. Finally, the analyses included the effects of colony density (colonies/ha; e.g. Sapir, Goldway, Shafir, \& Stern, 2007; Stern, Goldway, Zisovich, Shafir, \& Dag, 2004; Stern, Zisovich, Shafir, Dag, \& Goldway, 2005) or flower visitation rate (visit/flower; e.g. Artz \& Nault, 2011; Nicodemo, Couto, Malheiros, \& De Jong, 2009; Zhang et al., 2015) on fruit set (fruits/flower), seed set (seeds/fruit), fruit weight (g/fruit) or yield (kg/plant) (Table 1). Mean and standard error are presented for each of these effects. We also tested through linear and nonlinear (polynomial) regressions the influence of colony density on fruit set. The same analyses were performed to understand the influence of visitation rate on fruit set and seed set. Lack of replicates (at least 10 effect sizes) prevented similar analyses for other variables (see Table 1). For two of them, we also analysed the potential effect of the control level (lower level of the honeybee density for each effect size) as a predictor of the response ratio. We selected the best fit model according to the AIC.

To explain some of the variability in the effect sizes, we classified crops according to two traits expected to be relevant for pollination success, namely flower size and reproductive system (i.e. how female and male reproductive organs are distributed in individuals and flowers) (Fontaine, Dajoz, Meriguet, \& Loreau, 2006; Garibaldi et al., 2015). Even if there are other plant traits as sources of variation (e.g. concerning the degree of self-incompatibility of geitogamy), we chose to use simple and known indicators, available for all the studied crop species. The flower size classification was realized by the measure of the widest part and defined as "small" (1-35 mm) or "large" (>35 mm) (see Garibaldi et al., 2015). The classification according to the reproductive system of the flower separated plants with "hermaphrodite flowers," which present both male and female parts in the same flower, and from plants with "imperfect flowers," that is each flower presents only the female parts (pistil) or only the male parts (stamen). This category includes monoecious and dioecious plants (female and male flowers are present in the same individual or in separated individuals, respectively). However, for honeybee colony densities, the majority of the data came from plants with similar floral characteristics (out of 23 effect sizes, only two and three came from crops with large and hermaphroditic flowers, respectively), thus preventing comparative statistical analysis. For visitation rates, we pooled data on fruit set and seed set, as they showed similar responses (see Figure 2). This strategy increased the number of replicates for the analysis. We used $t$ tests to compare effect sizes for crops with contrasting flower sizes and reproductive systems. All the graphs and statistical analysis were computed using the R software version 3.4.2 (R Development Core Team, 2017).

\section{3 | RESULTS}

After the selection according to our criteria, only 22 studies on 16 cropping systems were included in our meta-analysis (Table 1). For example, three studies could not be included because they only provided the yield or another metric for a specific quantity of colonies or foragers in the field (without a comparison with another density 


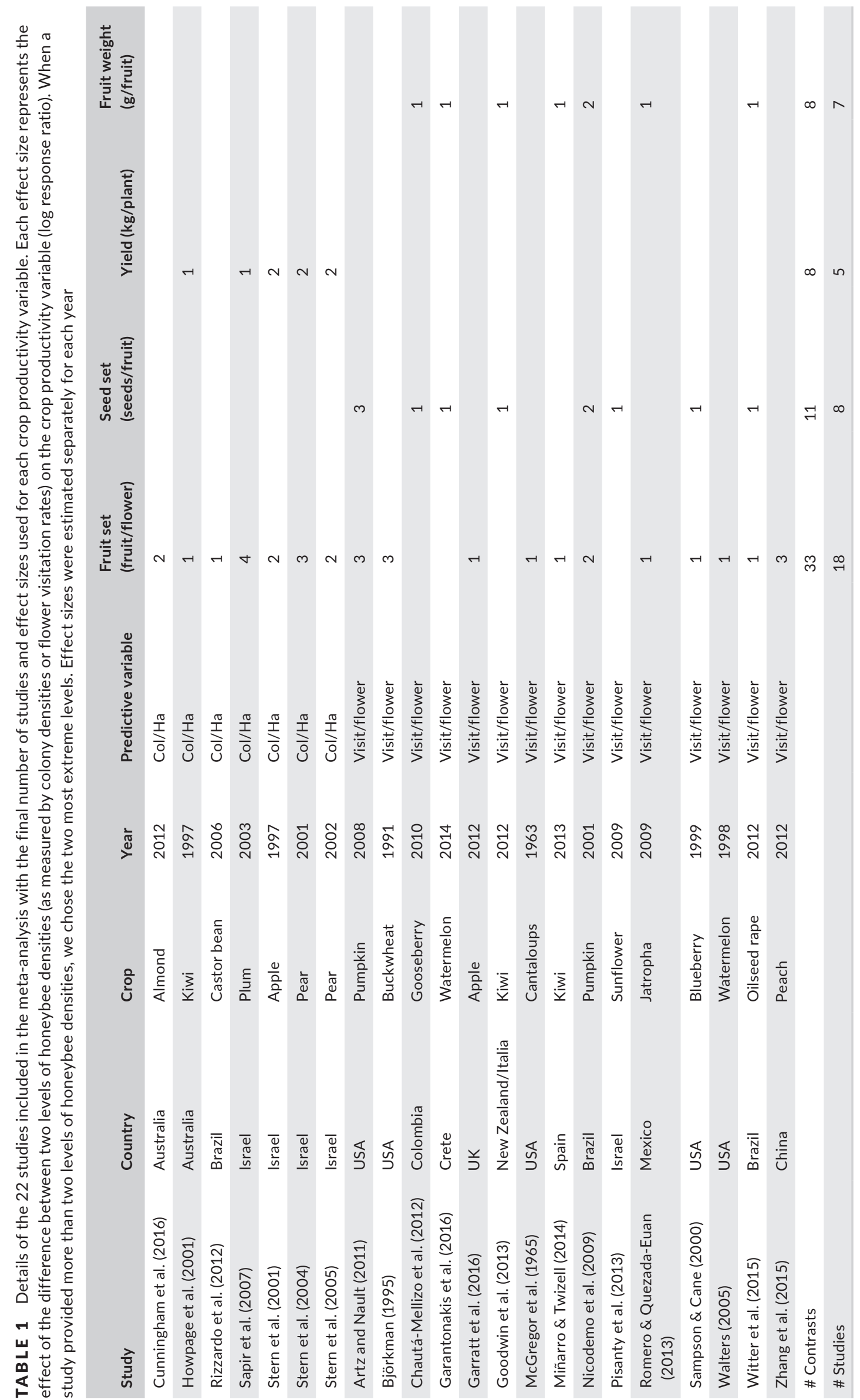




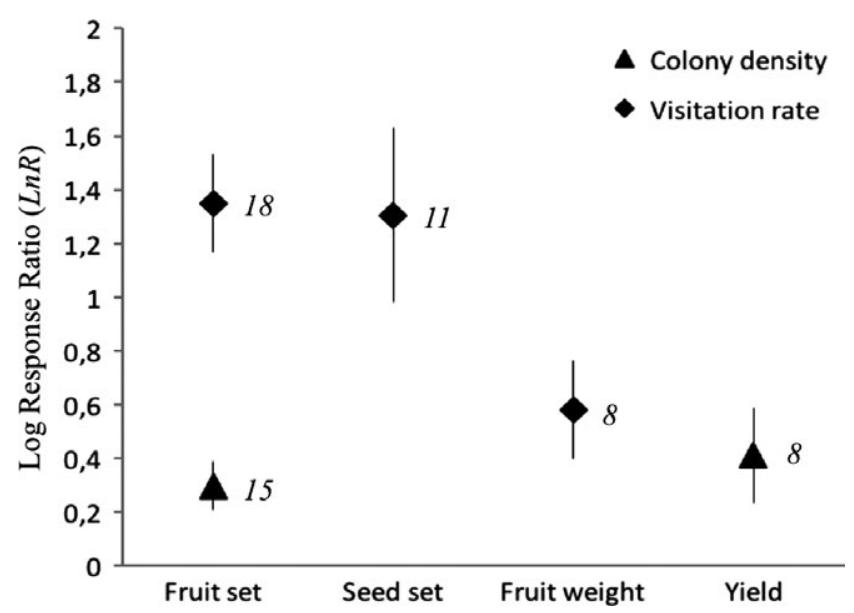

FIGURE 2 Positive effects of honeybee visitation rate or colony density on different seed or fruit productivity variables across crops world-wide. Points are mean values of the log response ratios, while bars represent one standard error. Numbers correspond to the sampling size

of honeybees). The selected studies are distributed across North America, South America, Europe, Africa, Asia and Oceania and the year of publication ranged from 1963 to 2014 . A total of 60 effect sizes were found suitable for the meta-analysis.

Among the 16 crop species, kiwi was the most represented with three studies, apple, pear, pumpkin and watermelon by two studies, while all the other crop species by only one study (Table 1). The most used response variables were the fruit set (fruits/flower), seed set (seeds/fruit), yield (kg/plant) and fruit weight (g/fruit) with 33, 11, 8 and 8 effect sizes, respectively (Table 1). The observed values of colony density were between 0 to 6.8 colonies per hectare, with delta values from 0.18 to 6 added colonies per hectare. The observed values for visitation rate were between 0 and 25 visits per flower, for a tested gradient from 1 to 24 added visits per flower. The maximum delta value for visitation rate was measured for an analysis of fruit set.

Globally, honeybees in the field, measured as colony density or visitation rate, increased crop productivity (Figure 2). This occurred for all the crop productivity variables analysed. For fruit set, effect sizes were smaller for colony density than for flower visitation rate $(t=5.19, p<0.001)$. Concerning the visitation rate, effect sizes were the same for seed set and fruit set $(t=-0.11, p=0.91)$. Effects sizes for fruit weight were smaller than those for fruit set $(t=2.63$, $p=0.016)$ and seed set $(t=1.95, p=0.06)$, but the latter trend was only marginally significant. Concerning colony density, effect sizes were similar for fruit set and yield ( $t=0.47, p=0.65$ ) (Figure 2). Effect sizes were not different between plants with large or small flowers ( $t=0.996, p=0.32$ ), while we found a significant higher response ratio for plants with imperfect flowers (monoecious and dioecious plants) than with hermaphroditic flowers ( $t=2.28, p=0.03$ ) (Figure 3).

We found a positive linear relationship between fruit set and colony density. However, the relationship between fruit set and

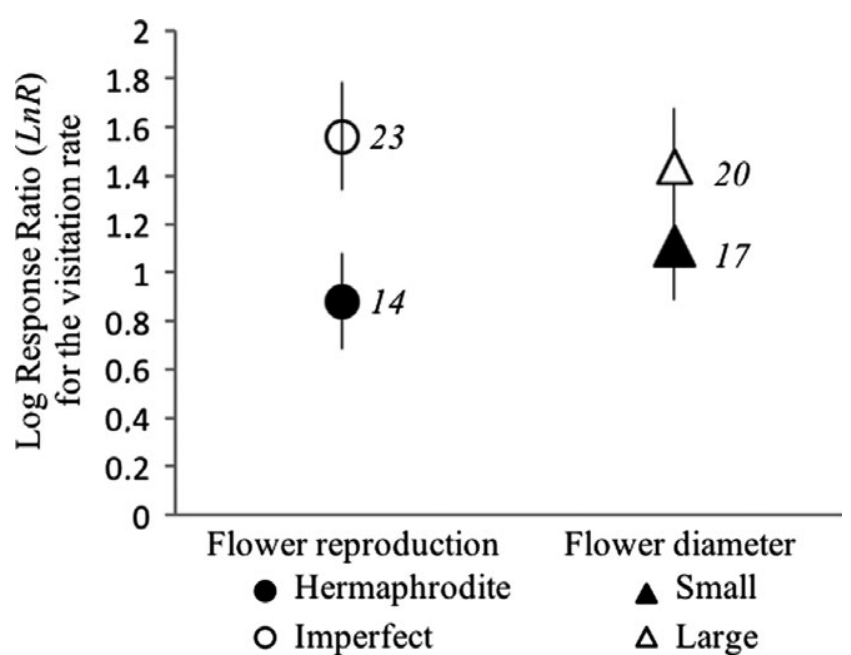

FIGURE 3 Effects of visitation rate on crop productivity (fruit and seed set) for crops with contrasting reproductive strategy and flower diameter. Points are mean values of the log response ratios, while bars represent one standard error. "Hermaphrodite" defines plants with both female and male parts in the same flower. "Imperfect" defines plants with female and male parts not in the same flower. Flower diameter at the widest part of the flower was classified as "small" (1-35 mm) or "large" (>35 mm) (see Garibaldi et al., 2015)

visitation rate was nonlinear $(\triangle \mathrm{AIC}=3.0)$, and a similar trend was found for seed set $(\triangle A I C=6.6$ ) (Figure 4). Interestingly, optimal levels of visitation rates (an increase of approximately 8-10 visits per flower) were similar for fruit set and seed set (Figure 4). Moreover, the log response ratio of the fruit set was higher for an increase in the visitation rate than for the increase in colony density, up to 2.94 for the visit rate, versus 1.29 for the colony density. Furthermore, when included as a co-variable, the base level (i.e. the absolute density of the control) had no effect on the observed pattern both for the visitation rate $(p=0.573$ and 0.844 on fruit set and seed set, respectively) and the colony density $(p=0.073)$.

\section{4 | DISCUSSION}

For many important crops, bee pollination translates into higher yield, higher seed or fruit quality and faster fruit ripening (Fries \& Stark, 1983; Lindström et al., 2015). In our meta-analysis, we have shown a positive effect of honeybee densities (as represented by colony density or flower visitation rates) on crop productivity (fruit set, seed set, fruit weight and/or yield). But this relationship seems to be nonlinear for the visitation rate (maximum increase in crop productivity when the visit rate per flower is increased by 8-10 additional visits relative to the baseline). Despite the world-wide importance of crop pollination by honeybees, surprisingly few studies analyse this question testing a large gradient of honeybee densities. Moreover, there is huge variability across studies in the measures selected to quantify the impact of honeybees on crop pollination or productivity. 
(a)

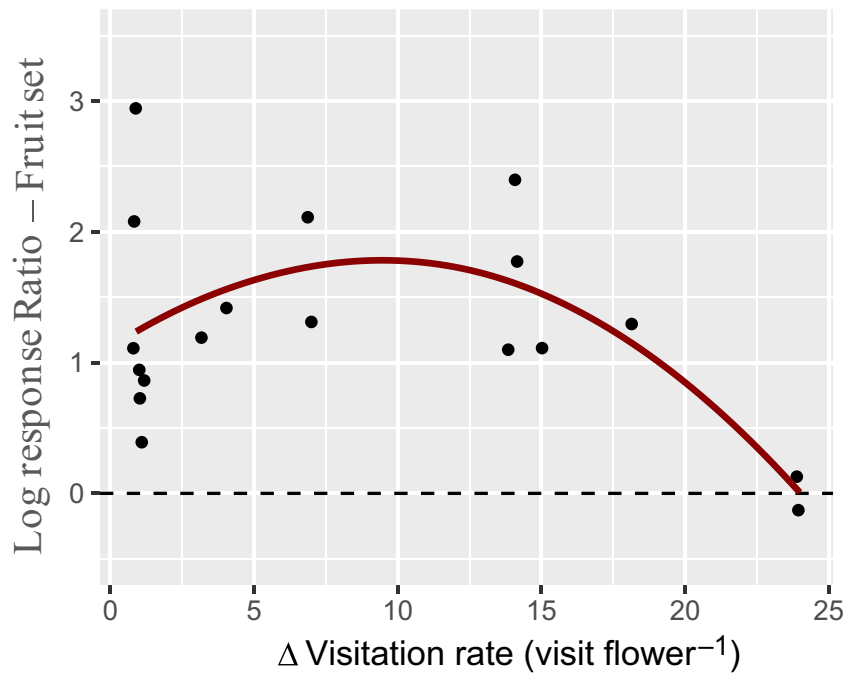

(c)

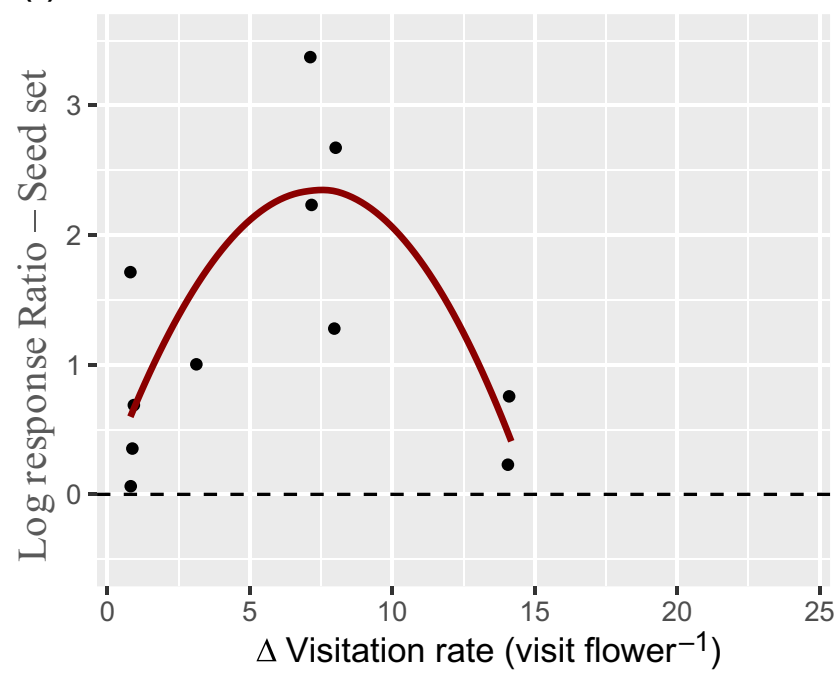

(b)

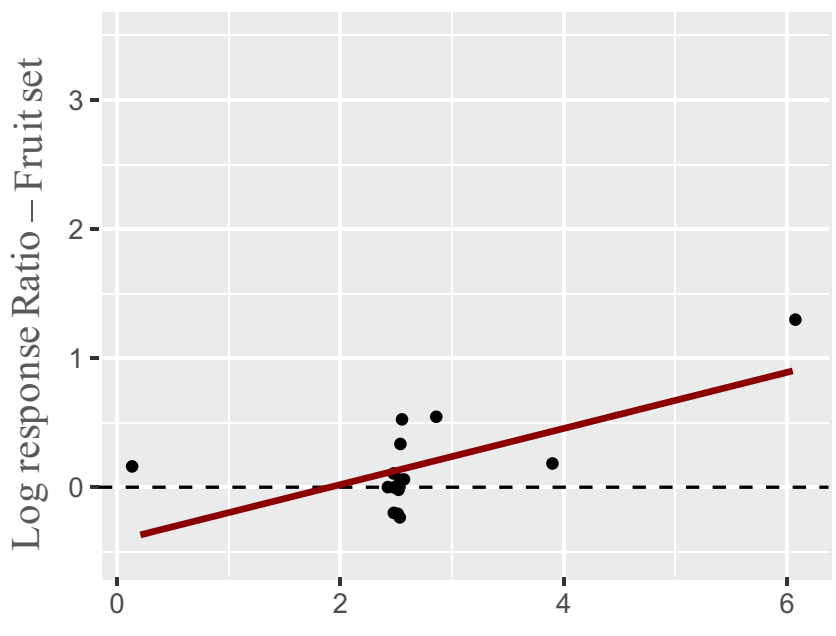

$\Delta$ Colony density (hive hectare ${ }^{-1}$ )

FIGURE 4 Effect size (log response ratio: InR) of fruit set (fruit flower ${ }^{-1}$; a, b) or seed set (seed fruit ${ }^{-1}$; c) according to the difference in honeybee visitation rate (visit flower ${ }^{-1}$; a c) or colony density (hive hectare ${ }^{-1}$; b). The dashed lines show a null log response ratio. The red lines show the polynomial (a, c) or linear (b) regressions. Only relationships with more than 10 data points are shown

\section{1 | Nonlinear responses}

The relationship with the response ratio differed according to the observed predictive variable. The effects of visitation rate on fruit set or seed set were nonlinear. Higher visitation rates increase fruit and seed productivity but after an optimal increase in the visitation rate (around eight more visits per flower) this effect is smaller becoming negative when the number of visits per flower increases by more than 22 visits (in the case of the fruit set). Some studies have shown or predicted a saturation and/or a significant decline in fruit-set with pollinator abundance, as for bumble bees (Sáez et al., 2014) or beetles (Young, 1988), due to an increase in the ratio cost/ benefit of insect pollination (Morris et al., 2010). One explanation is that high visitation frequency can lead to cumulative damages of stigmatic surfaces or other female reproductive organs by repetitive contacts (Sáez et al., 2014). Moreover, a surplus of pollen deposition leads to a stagnation of pollen grains or pollen tubes, which can interfere with each other and reduce the fertilization (Young \& Young, 1992).

In contrast, the relationship between colony density and fruit set seems to be linear and positive. One explanation could be that observed colony densities were not high enough to detect nonlinear patterns in crop productivity. Indeed, the reviewed studies analyse gradients of colony densities smaller than those proposed in the literature for practical recommendations (compare colony densities in Figure 4 to those in Figure 1). For example, the recommendation for apple pollination ranges from 1 to 16 colonies per hectare (Figure 1), but the colony densities used in the studies included in our metaanalysis ranged from 2.5 to 5 colonies per hectare (Figure 4). Similarly, for cranberry, studies reviewed for the meta-analysis ranged from 0 to 7.4 colonies per hectare while the recommendation in the book by Delaplane and Mayer (2000) ranges from 1 to 
22 colonies per hectare (however for cranberry, studies reviewed and selected after full-text assessment, were not finally included in the meta-analysis due to various problems with data quality). These observations confirm that we need studies with a greater gradient of colony densities and more replicates.

\section{2 | Effect sizes depend on flower reproductive traits}

The effects of visitation rate on fruit and seed sets were higher for plants with imperfect flowers than for plants with hermaphroditic flowers (Figure 3). Such differences in the response intensity might be tied to the degree of dependence of the plant on cross-pollination by insects. This dependence varies with the level of self-fertility of the plant and the flower morphology (Delaplane \& Mayer, 2000). Generally, monoecious and dioecious plants are more dependent on insect pollination than hermaphroditic plants, and need insects, especially bees, as pollen vectors. In contrast, plants with hermaphroditic flowers generally have a higher degree of self-pollination (Morris et al., 2010).

However, although the effect size on plants with hermaphroditic flowers is lower, the increase in honeybee visitation rate significantly increases crop productivity. Hermaphroditic flowers present a perfect structure to perform a full self-pollination. But to prevent inbreeding and promote genetic diversity, many species use cross-pollination and develop self-incompatibility mechanisms, such as temporal separation of the male and female phases (pollen production and stigma receptivity) (Barbier, 1986; Delaplane \& Mayer, 2000; Rollin et al., 2016). For example, raspberry crops are fully self-fertile but the production of well-formed fruits depends on animal pollination (Cane, 2005; Morales, 2009; Sáez et al., 2014). Therefore, honeybee or bumblebee hives are commonly deployed in raspberry fields to ensure an adequate pollination (Garibaldi et al., 2017; Velthuis \& van Doorn, 2006) and increase crop productivity.

\subsection{Use of the visitation rate to adjust colony management}

Honeybee densities in the crops were represented most frequently by counting colonies per hectare or visits per flower. We found greater effects sizes for visitation rate than for colony density. Visitation rates could be more relevant than colony density for several reasons.

First, density is only one measure of colony management. The spatial and temporal arrangements of the colonies can have different impacts on crop pollination and productivity. Indeed, colony density can be characterized as a function of the number of colonies per placement and the distance between each placement (see Cunningham et al., 2016). The percentage of flowers converted into fruit and the yield increases with colony density but decreases significantly when the distance from the crop to the colony placements increases (Cunningham et al., 2016; Manning \& Wallis, 2005). Moreover, some studies have shown the variability of the effect of a given colony density, according to multiple introductions of colonies for some crops like pear (Stern et al., 2004, 2005), apple (Stern, Eisikowitch, \& Dag, 2001) and plum (Sapir et al., 2007). A sequential introduction of honeybee colonies enhanced bee pollination activity, with a higher honeybee visitation rate (bee $\min ^{-1}$ tree $^{-1}$ ). These multiple introductions can give the same or a higher fruit set and yield than a two times higher colony density with a single introduction. This point confirms that the relationship between crop productivity and colony density depends on other important management decisions.

Second, colonies can be very different in terms of quality and quantity of bees and can vary during the flowering season. For example, the size of a colony can vary greatly from 10,000 and 40,000 individuals across studies (10,000 in Hansted, Grout, ToldamAndersen, \& Eilenberg, 2015; 20,000 in Stern et al., 2001; 25,000 in Walters, 2005; 30,000 in Aras, De Oliveira, \& Savoie, 1996; 40,000 in Quinet et al., 2016). Another point concerns the plasticity of the working organization in the colony to respond to environmental changes. Between $2 \%$ and $10 \%$ of the total population size of the colony are available daily for foraging (Seeley, 1985), and usually concerne the older individuals, because foraging is the last function of the worker (Menzel et al., 2005). But this percentage can show strong temporal variations (e.g. from $0 \%$ to $68 \%$ of the workers on a given day; Thom, Seeley, \& Tautz, 2000), according to the quantity and quality of the reserves in the colony and the available pollen and nectar resources in the surrounding landscape (Beekman, Sumpter, Seraphides, \& Ratnieks, 2004; Odoux et al., 2014). Moreover, some pathogens or viruses can cause damage in the population, or even the death of some colonies. So the number of bee foragers can vary greatly from one colony to another, as their resistance to other environmental perturbations (climate, other pathogens and/or viruses, predators). This can have various consequences on the composition and the dynamics of the population, and the colony survival (Deleplane \& Mayer, 2000).

Third, a higher number of colonies per hectare does not necessarily imply an increase in honeybee foragers in the field. Movements across habitats are a common phenomenon in many species. For their diet, honeybees forage on a wide diversity of floral resources spatially separated in the landscape, from both crops fields and non-cropped habitats (Odoux et al., 2012; Requier et al., 2015; Rollin et al., 2013) and need to make cross-habitat movements, including spillover from crops (where colonies are placed) to semi-natural habitats (Blitzer et al., 2012; Hanley et al., 2011; Tscharntke et al., 2012). Moreover, they can alter their foraging behaviour in response to the availability of floral resources in the landscape. They preferentially forage in the crop when alternative resources are scarce in the surrounding landscape, but they can move away from a crop to a semi-natural habitat if it presents a more attractive floral resource than the crop (GainesDay \& Gratton, 2016; Pettis et al., 2013; Vaissiere, 1991). In this context, increasing the number of colonies in the landscape, and consequently, the number of honeybee foragers, does not necessarily signify a proportional increase of honeybee foragers in the targeted crop and higher pollination. 
Finally, the flower quantity per plant (or tree) can change with intra- and inter-annual variations. Especially in fruit crops (or tree crops), the density of flowers produced by plants, and therefore crop productivity, increases during approximately the first 7 years and then stabilizes. Adult crops, at their maximal productivity level, can produce one or two orders of magnitude more flowers than when they began to produce. For this reason, some studies recommend different colony densities according to the age of the trees. For example, Delaplane and Mayer (2000) advise one colony per hectare for young peach trees and 2.5 colonies per hectare for older trees. In the USA in almond orchards, 2.5 colonies per hectare are placed during the first and second year of production because the trees are small. Then, it is advised to use 5-6.25 colonies per hectare (A. Sáez, pers. com., 2017).

Thus, the recommended colony density depends on the attractiveness of the crop, the composition, abundance and attractiveness of the other competing floral resources in the landscape, the population density and composition of non-managed bees, the location and strength of honeybee colonies and other environmental variables like the climate. All these variables can result in strong variations in the density of honeybee foragers in the crop and consequently change the pollination success of honeybees and crop productivity. For these reasons, visitation rate rather than colony density would be a more precise measure for assessing the pollination service by honeybees.

However, routine management practices in bee pollination use the honeybee colony as a management unit, with beekeeper and farmer agreeing on a renting price per colony according to the pollinated crop, the pollination time and the distance that the beekeeper must travel to drop off the hives at the field crop (e.g. websites to optimize communication between beekeepers and farmers for pollination service; http://www.beewapi.com/). Thus, characterizing the relationship between colony density and crop productivity is very important, from the point of view of applied management and communication between beekeepers and farmers. Moreover, pollination services need standardized and strong colonies. The measure of field colony strength generally means population measures of adult bees and brood (a) by an observer at the beginning of a study or a pollination service to produce uniform colonies, or after an experiment, to evaluate a specific impact on the colonies or (b) by computer-assisted digital image analysis (Delaplane, Van der Steen, \& Guzman, 2013). We can also use other indirect variables, such as drone brood production, queen cell production, comb construction or flight activity at the entrance of the hive. For example, the ColEval method (Maisonnasse et al., 2016) is based on the evaluation of the percentage of surface area occupied by five different components of the colony structure to determine colony performance: the number of bees, the amount of open brood and capped brood, the quantity of food (honey and nectar) and pollen. This method eliminates bias in the measurements between observers. Moreover, it also proposes, a posteriori an estimation of the number of honeybee foragers and, therefore, the potential pollination strength of a colony.
Developing these estimators is a key step in evaluating the link between colony strength, visitation rate and maximal pollination service. Once this relationship is characterized, we could compare the real visitation rate in one crop system with a theoretical optimal visitation rate and adjust the number of colonies and/or their placement (distance) to reduce or increase the observed visitation rate.

\subsection{A lack of standardization}

One of the major difficulties encountered in our meta-analysis was the lack of standardized methods and common metrics to analyse the impact of honeybees on pollination success or crop productivity. For example, honeybee management was measured as the number of colonies per hectare (Stern et al., 2001, 2004, 2005), number of colonies per field (without information about field size) (Walters \& Taylor, 2006), number of introduced foragers (Fulton, Jesson, Bobiwash, \& Schoen, 2015), number of bees per tree (for orchards) (Costa, Testolin, \& Vizzotto, 1993), number of bees per tree per minute of observation (Sapir et al., 2007), number of bee visits per flower (Björkman, 1995), number of bee visits per minute (Dedej \& Delaplane, 2003), number of bees per 100 flowers (Aras et al., 1996) or number of bees per $100 \mathrm{~m}^{2}$ (Evans \& Spivak, 2006). Similar complexity was observed for crop productivity, with studies measuring fruit set, number of fruits per 10 shrubs, yield per tree (in orchards), yield per $100 \mathrm{~m}^{2}$, seed set, number of seeds per fruit, number of seeds per kg of fruit, fruit size (circumference), fruit length or fruit weight. Consequently, we found varying combinations of measures of honeybee density and crop productivity but with few replicates, which did not allow for comparison across studies and reduced the effective database (see Table 1). Future studies should follow more standardized reporting procedures to permit a statistical comparison between crops and environmental contexts. It is with this same objective that the Food and Agriculture Organization of the United Nations (FAO; http://www.fao.org/home/en/) published in 2011 a document to detect and measure pollination deficits in crops (Vaissière, Freitas, \& Gemmill-Herren, 2011). This handbook presents a standardized protocol, and the modifications and applications of this protocol for a variety of circumstances in developing and developed countries, such as those with high environmental variability and small fields. Some projects have started using this protocol and consequently, they will give comparable data (Garibaldi et al., 2016).

\subsection{Synthesis and applications}

Currently, the global demand for honeybee colonies for the pollination of fruit crops is growing (Aizen \& Harder, 2009). In various countries worldwide, this demand shows a more rapid growth than the number of colonies available for pollination (Aizen, Garibaldi, Cunningham, \& Klein, 2008; Aizen \& Harder, 2009). Our study shows that both the visitation rate of honeybees and the number of honeybee colonies in the crops increase seed and fruit productivity worldwide. However, in contrast to current management assumptions 
(Garibaldi et al., 2017; James \& Pitts-Singer, 2008), the relationship seems to be nonlinear for visitation rate. Current studies are not designed for finding such an optimal level of honeybee hive densities or honeybee visitation rates, and the relationship between colony densities and visitation rates is still unclear. These findings open new important avenues of research. Future studies should measure colony strength, and take into account crop pollination need and the presence of wild pollinators in the landscape of the considered crops to determine the optimal level of honeybee densities.

\section{ACKNOWLEDGEMENTS}

This work was supported by the Agencia Nacional de Promoción Científica y Tecnológica (PICT 2013-1079), Consejo Nacional de Investigaciones Científicas y Técnicas (PDTS Res 298/14, Exp 8383/13), and Universidad Nacional de Río Negro (PI 40-B-399 and PI 40-B-567). We are grateful to Marcelo A. Aizen, Jeferson G. Coutinho, Nestor Perez-Mendez, Carolina L. Morales, Fabrice Requier and Agustín Sáez for their constructive corrections. We also thank the three anonymous reviewers for their input to our manuscript.

\section{AUTHORS' CONTRIBUTIONS}

O.R. and L.A.G. conceived the ideas, designed research, and wrote the manuscript; O.R. collected and analysed the data; O.R. and L.A.G. interpreted the data. Both authors gave final approval for publication.

\section{DATA ACCESSIBILITY}

Data available from the Dryad Digital Repository https://doi. org/10.5061/dryad.dj5f7kc (Rollin \& Garibaldi, 2019).

\section{ORCID}

Orianne Rollin (iD https://orcid.org/0000-0002-1455-9302

Lucas A. Garibaldi iD https://orcid.org/0000-0003-0725-4049

\section{REFERENCES}

Aizen, M. A., Garibaldi, L. A., Cunningham, S. A., \& Klein, A. M. (2008). Long-term global trends in crop yield and production reveal no current pollination shortage but increasing pollinator dependency. Current Biology, 18, 1572-1575. https://doi.org/10.1016/j.cub.2008.08.066

Aizen, M. A., \& Harder, L. D. (2009). The global stock of domesticated honeybees is growing slower than agricultural demand for pollination. Current Biology, 19, 915-918. https://doi.org/10.1016/ j.cub.2009.03.071

Aizen, M. A., Morales, C. L., Vázquez, D. P., Garibaldi, L. A., Sáez, A., \& Harder, L. D. (2014). When mutualism goes bad: Density-dependent impacts of introduced bees on plant reproduction. New Phytologist, 204, 322-328. https://doi.org/10.1111/nph.12924

Aras, P., De Oliveira, D., \& Savoie, L. (1996). Effect of a honeybee (Hymenoptera: Apidae) gradient on the pollination and yield of lowbush blueberry. Journal of Economic Entomology, 89, 1080-1083. https://doi.org/10.1093/jee/89.5.1080
Artz, D. R., \& Nault, B. A. (2011). Performance of Apis mellifera, Bombus impatiens, and Peponapis pruinosa (Hymenoptera: Apidae) as pollinators of pumpkin. Journal of Economic Entomology, 104, 1153-1161. https://doi.org/10.1603/EC10431

Barbier, E. (1986). La pollinisation des cultures: pourquoi? Comment. Le Pontet, France: Chez l'auteur.

Beekman, M., Sumpter, D. J. T., Seraphides, N., \& Ratnieks, F. L. W. (2004). Comparing foraging behaviour of small and large honey-bee colonies by decoding waggle dances made by foragers. Functional Ecology, 18, 829-835. https://doi.org/10.1111/j.0269-8463.2004.00924.x

Björkman, T. (1995). Role of honeybees (Hymenoptera: Apidae) in the pollination of buckwheat in eastern North America. Journal of Economic Entomology, 88, 1739-1745. https://doi.org/10.1093/jee/88.6.1739

Blitzer, E. J., Dormann, C. F., Holzschuh, A., Klein, A.-M., Rand, T. A., \& Tscharntke, T. (2012). Spillover of functionally important organisms between managed and natural habitats. Agriculture, Ecosystems and Environment, 146, 34-43. https://doi.org/10.1016/j.agee.2011.09.005

Borenstein, M., Hedges, L. V., Higgins, J. P. T., \& Rothstein, H. R. (2009). Introduction to meta-analysis (1st ed.). Chichester, UK: WileyBlackwell. https://doi.org/10.1002/9780470743386

Brittain, C., Williams, N., Kremen, C., \& Klein, A.-M. (2013). Synergistic effects of non-Apis bees and honeybees for pollination services. Proceedings of the Royal Society B: Biological Sciences, 280, 2012276720122767. https://doi.org/10.1098/rspb.2012.2767

Burkle, L. A., Marlin, J. C., \& Knight, T. M. (2013). Plant-pollinator interactions over 120 years: Loss of species, co-occurrence, and function. Science, 339, 1611-1615. https://doi.org/10.1126/science.1232728

Cane, J. H. (2005). Pollination potential of the bee Osmia aglaia for cultivated red raspberries and blackberries (Rubus: Rosaceae). HortScience, 40, 1705-1708. https://doi.org/10.21273/HORTSCI.40.6.1705

Costa, G., Testolin, R., \& Vizzotto, G. (1993). Kiwifruit pollination: An unbiased estimate of wind and bee contribution. New Zealand Journal of Crop and Horticultural Science, 21, 189-195. https://doi.org/10.1080/ 01140671.1993.9513767

Crane, E. (1999). The world history of beekeeping and honey hunting. London: Gerald Duckworth \& Co.

Chautá-Mellizo, A., Campbell, S. A., Bonilla, M. A., Thaler, J. S., \& Poveda, K. (2012). Effects of natural and artificial pollination on fruit and offspring quality. Basic and Applied Ecology, 13, 524-532. https://doi. org/10.1016/j.baae.2012.08.013

Cunningham, S. A., Fournier, A., Neave, M. J., \& Le Feuvre, D. (2016). Improving spatial arrangement of honeybee colonies to avoid pollination shortfall and depressed fruit set. Journal of Applied Ecology, 53, 350-359. https://doi.org/10.1111/1365-2664.12573

Dedej, S., \& Delaplane, K. S. (2003). Honeybee (Hymenoptera: Apidae) pollination of rabbiteye blueberry Vaccinium ashei var. 'Climax' is pollinator density-dependent. Journal of Economic Entomology, 96, 1215-1220. https://doi.org/10.1093/jee/96.4.1215

Delaplane, K. S., \& Mayer, D. F. (2000). Crop Pollination by Bees. Wallingford, UK: CABI Publishing.

Delaplane, K. S., Van der Steen, J., \& Guzman, E. (2013). Standard methods for estimating strength parameters of Apis mellifera colonies. Journal of Apicultural Research, 52(1), 1-12.

Dennis, B., \& Kemp, W. P. (2016). How hives collapse: Allee effects, ecological resilience, and the honeybee. PLoS ONE, 11, e0150055. https://doi.org/10.1371/journal.pone.0150055

Department of Agriculture and Food. (2006). Bee pollination benefits for nut crops. Retrieved from http://archive.agric.wa.gov.au/PC $94129 \mathrm{html}$ s $=262070423$

vanEngelsdorp, D., \& Meixner, M. D. (2010). A historical review of managed honeybee populations in Europe and the United States and the factors that may affect them. Journal of Invertebrate Pathology, 103, S80-S95. https://doi.org/10.1016/j.jip.2009.06.011

Evans, E. C., \& Spivak, M. (2006). Effects of honeybee (Hymenoptera: Apidae) and bumble bee (Hymenoptera: Apidae) presence on 
cranberry (Ericales: Ericaceae) pollination. Journal of Economic Entomology, 99, 614-620. https://doi.org/10.1093/jee/99.3.614

Fontaine, C., Dajoz, I., Meriguet, J., \& Loreau, M. (2006). Functional diversity of plant-pollinator interaction webs enhances the persistence of plant communities. PLoS Biology, 4, e1.

Free, J. B. (1993). Insect pollination of crops (2nd ed.). London: Academic Press.

Fries, I., \& Stark, J. (1983). Measuring the importance of honeybees in rape seed production. Journal of Apicultural Research, 22(4), 272-276. https://doi.org/10.1080/00218839.1983.11100599

Fulton, M., Jesson, L. K., Bobiwash, K., \& Schoen, D. J. (2015). Mitigation of pollen limitation in the lowbush blueberry agroecosystem: Effect of augmenting natural pollinators. Ecosphere, 6, 1-19.

Gaines-Day, H. R. (2013). Do bees matter to cranberry? The effect of bees, landscape, and local management on cranberry yield. University of Wisconsin-Madison: Ed ProQuest LLC.

Gaines-Day, H. R., \& Gratton, C. (2016). Crop yield is correlated with honeybee hive density but not in high-woodland landscapes. Agriculture, Ecosystems \& Environment, 218, 53-57. https://doi.org/10.1016/j.agee.2015.11.001

Garantonakis, N., Varikou, K., Birouraki, A., Edwards, M., Kalliakaki, V., \& Andrinopoulos, F. (2016). Comparing the pollination services of honey bees and wild bees in a watermelon field. Scientia Horticulturae, 204, 138-144. https://doi.org/10.1016/j.scienta.2016.04.006

Garratt, M. P. D., Breeze, T. D., Boreux, V., Fountain, M. T., McKerchar, M., Webber, S. M., ... Potts, S. G. (2016). Apple pollination: Demand depends on variety and supply depends on pollinator identity. PLOS ONE, 11(5), e0153889. https://doi.org/10.1371/journal.pone.0153889

Garibaldi, L. A., Bartomeus, I., Bommarco, R., Klein, A. M., Cunningham, S. A., Aizen, M.A.,...Woyciechowski, M.(2015). Traitmatching of flowervisitors and crops predicts fruit set better than trait diversity. Journal of Applied Ecology, 52, 1436-1444. https://doi.org/10.1111/1365-2664.12530

Garibaldi, L. A., Carvalheiro, L. G., Vaissiere, B. E., Gemmill-Herren, B., Hipolito, J., Freitas, B. M., ... Zhang, H. (2016). Mutually beneficial pollinator diversity and crop yield outcomes in small and large farms. Science, 351, 388-391.

Garibaldi, L. A., Requier, F., Rollin, O., \& Andersson, G. K. S. (2017). Towards an integrated species and habitat management of crop pollination. Current Opinion in Insect Science, 21, 105-114.

Garibaldi, L. A., Steffan-Dewenter, I., Winfree, R., Aizen, M. A., Bommarco, R., Cunningham, S. A., ... Klein, A. M. (2013). Wild pollinators enhance fruit set of crops regardless of honeybee abundance. Science, 340(6127), 1608-1611.

Goodwin, R., McBrydie, H., \& Taylor, M. (2013). Wind and honey bee pollination of kiwifruit (Actinidia chinensis "HORT16A"). New Zealand Journal of Botany, 51, 229-240. https://doi.org/10.1080/0028825x.2013.806934

Goulson, D., Nicholls, E., Botías, C., \& Rotheray, E. L. (2015). Bee declines driven by combined stress from parasites, pesticides, and lack of flowers. Science, 347, 1255957. https://doi.org/10.1126/science.1255957

Hanley, M. E., Franco, M., Dean, C. E., Franklin, E. L., Harris, H. R., Haynes, A. G., ... Knight, M. E. (2011). Increased bumblebee abundance along the margins of a mass flowering crop: Evidence for pollinator spill-over. Oikos, 120, 1618-1624. https://doi.org/10.1111/j.1600-0706.2011.19233.x

Hansted, L., Grout, B. W. W., Toldam-Andersen, T. B., \& Eilenberg, J. (2015). Effectiveness of managed populations of wild and honeybees as supplemental pollinators of sour cherry (Prunus cerasus L.) under different climatic conditions. Acta Agriculturae Scandinavica, Section B - Soil \& Plant Science, 65, 109-117.

Hargreaves, A. L., Harder, L. D., \& Johnson, S. D. (2009). Consumptive emasculation: The ecological and evolutionary consequences of pollen theft. Biological Reviews, 84, 259-276. https://doi. org/10.1111/j.1469-185X.2008.00074.x

Hargreaves, A. L., Harder, L. D., \& Johnson, S. D. (2010). Native pollen thieves reduce the reproductive success of a hermaphroditic plant, Aloe maculata. Ecology, 91, 1693-1703. https://doi.org/10.1890/09-0792.1
Holzschuh, A., Dainese, M., González-Varo, J. P., Mudri-Stojnić, S., Riedinger, V., Rundlöf, M., ... Steffan-Dewenter, I. (2016). Mass-flowering crops dilute pollinator abundance in agricultural landscapes across Europe. Ecology Letters, 19, 1228-1236. https://doi.org/10.1111/ele.12657

Howpage, D., Spooner-Hart, R. N., \& Vithanage, V. (2001). Influence of honey bee (Apis mellifera) on kiwifruit pollination and fruit quality under Australian conditions. New Zealand Journal of Crop and Horticultural Science, 29, 51-59. https://doi.org/10.1080/01140671.2001.9514160

Howlett, B. G., Nelson, W. R., Pattemore, D. E., \& Gee, M. (2015). Pollination of macadamia: Review and opportunities for improving yields. Scientia Horticulturae, 197, 411-419. https://doi.org/10.1016/j. scienta.2015.09.057

Isaacs, R., \& Kirk, A. K. (2010). Pollination services provided to small and large highbush blueberry fields by wild and managed bees. Journal of Applied Ecology,47,841-849.https://doi.org/10.1111/j.1365-2664.2010.01823.x

James, R. R., \& Pitts-Singer, T. L. (2008). Bee pollination in agricultural ecosystems. Oxford: Oxford University Press.

Le duc, I., \& Turcotte, C. (2004). Manuel de lutte intégrée de la canneberge de l'est canadien. Ottawa: Agence de réglementation de la lutte antiparasitaire.

Lindström, S. A. M., Herbertsson, L., Rundlöf, M., Smith, H. G., \& Bommarco, R. (2015). Large-scale pollination experiment demonstrates the importance of insect pollination in winter oilseed rape. Oecologia, 180(3), 759-769. https://doi.org/10.1007/s00442-015-3517-x

Maisonnasse, A., Hernandez, J., Le Quintrec, C., Cousin, M., Beri, C., \& Kretzschmar, A. (2016). Evaluation de la structure des colonies d'abeilles, création et utilisation de la méthode ColEval (Colony Evaluation). Innovations Agronomiques, 53, 27-37.

Mallinger, R. E., Gaines-Day, H. R., \& Gratton, C. (2017). Do managed bees have negative effects on wild bees?: A systematic review of the literature. PLOS ONE, 12, e0189268. https://doi.org/10.1371/journal. pone. 0189268

Manning, R., \& Wallis, I. R. (2005). Seed yields in canola (Brassica napus $\mathrm{cv}$. Karoo) depend on the distance of plants from honeybee apiaries. Australian Journal of Experimental Agriculture, 45, 1307-1313. https:// doi.org/10.1071/EA02170

Mcgregor, S. E., Levin, M. D., \& Foster, R. E. (1965). Honey bee visitors and fruit set of Cantaloups1. Journal of Economic Entomology, 58(5), 968-970. https://doi.org/10.1093/jee/58.5.968

Menzel, R., Greggers, U., Smith, A., Berger, S., Brandt, R., Brunke, S., ... Watzl, S. (2005). Honeybees navigate according to a map-like spatial memory. Proceedings of the National Academy of Sciences of the United States of America, 102, 3040-3045. https://doi.org/10.1073/pnas.0408550102

Michener, C. D. (2007). The bees of the world, 2nd revised ed. Baltimore, Maryland: The Johns Hopkins University Press.

Miñarro, M., \& Twizell, K. W. (2014). Pollination services provided by wild insects to kiwifruit (Actinidia deliciosa). Apidologie, 46(3), 276-285. https://doi.org/10.1007/s13592-014-0321-2

Morales, C. L. (2009). Pollination requirement of raspberry in SW Argentina. Preliminary results. The International Journal of Plant Reproductive Biology, 1, 195-198.

Morris, W. F., Vázquez, D. P., \& Chacoff, N. P. (2010). Benefit and cost curves for typical pollination mutualisms. Ecology, 91, 1276-1285. https://doi.org/10.1890/08-2278.1

Nicodemo, D., Couto, R. H. N., Malheiros, E. B., \& De Jong, D. (2009). Honeybee as an effective pollinating agent of pumpkin. Scientia Agricola, 66, 476-480. https://doi.org/10.1590/S0103-90162009000400007

Odoux, J.-F., Aupinel, P., Gateff, S., Requier, F., Henry, M., \& Bretagnolle, V. (2014). ECOBEE: A tool for long-term honeybee colony monitoring at the landscape scale in West European intensive agroecosystems. Journal of Apicultural Research, 53, 57-66. https://doi.org/10.3896/IBRA.1.53.1.05

Odoux, J.-F., Feuillet, D., Aupinel, P., Loublier, Y., Tasei, J.-N., \& Mateescu, C. (2012). Territorial biodiversity and consequences on physico-chemical characteristics of pollen collected by honeybee colonies. Apidologie, 43, 561-575. https://doi.org/10.1007/s13592-012-0125-1 
Pettis, J. S., Lichtenberg, E. M., Andree, M., Stitzinger, J., Rose, R., \& vanEngelsdorp, D. (2013). Crop pollination exposes honeybees to pesticides which alters their susceptibility to the gut pathogen Nosema ceranae. PLoS ONE, 8, e70182. https://doi.org/10.1371/journal.pone.0070182

Pisanty, G., Klein, A.-M., \& Mandelik, Y. (2013). Do wild bees complement honeybee pollination of confection sunflowers in Israel? Apidologie, 45(2), 235-247. https://doi.org/10.1007/s13592-013-0242-5

Quinet, M., Warzée, M., Vanderplanck, M., Michez, D., Lognay, G., \& Jacquemart, A.-L. (2016). Do floral resources influence pollination rates and subsequent fruit set in pear (Pyrus communis L.) and apple (Malus $\times$ domestica Borkh) cultivars? European Journal of Agronomy, 77, 59-69. https://doi.org/10.1016/j.eja.2016.04.001

R Development Core Team. (2017). R: A language and environment for statistical computing, version 3.4.2. Vienna, Austria: R Foundation for Statistical Computing.

Requier, F., Odoux, J.-F., Tamic, T., Moreau, N., Henry, M., Decourtye, A., \& Bretagnolle, V. (2015). Honeybee diet in intensive farmland habitats reveals an unexpectedly high flower richness and a major role of weeds. Ecological Applications, 25, 881-890. https://doi. org/10.1890/14-1011.1

Rizzardo, R. A. G., Milfont, M. O., da Silva, E. M. S., \& Freitas, B. M. (2012). Apis mellifera pollination improves agronomic productivity of anemophilous castor bean (Ricinus communis). Anais Da Academia Brasileira de Ciências, 84, 1137-1145. https://doi.org/10.1590/ s0001-37652012005000057

Rollin, O., Benelli, G., Benvenuti, S., Decourtye, A., Wratten, S. D., Canale, A., \& Desneux, N. (2016). Weed-insect pollinator networks as bio-indicators of ecological sustainability in agriculture. A review. Agronomy for Sustainable Development, 36, 1-22.

Rollin, O., Bretagnolle, V., Decourtye, A., Aptel, J., Michel, N., Vaissière, B. E., $\&$ Henry, M. (2013). Differences of floral resource use between honeybees and wild bees in an intensive farming system. Agriculture, Ecosystems \& Environment, 179, 78-86. https://doi.org/10.1016/j.agee.2013.07.007

Rollin, O., \& Garibaldi, L. A. (2019). Data from: Impacts of honeybee density on crop yield: A meta-analysis. Dryad Digital Repository, https:// doi.org/10.5061/dryad.dj5f7kc

Romero, M. J., \& Quezada-Euán, J. J. G. (2013). Pollinators in biofuel agricultural systems: The diversity and performance of bees (Hymenoptera: Apoidea) on Jatropha curcas in Mexico. Apidologie, 44(4), 419-429. https://doi.org/10.1007/s13592-013-0193-x

Russell, S., Barron, A. B., \& Harris, D. (2013). Dynamic modelling of honey bee (Apis mellifera) colony growth and failure. Ecological Modelling, 265, 158-169. https://doi.org/10.1016/j.ecolmodel.2013.06.005

Sáez, A., Morales, C. L., Ramos, L. Y., \& Aizen, M. A. (2014). Extremely frequent bee visits increase pollen deposition but reduce drupelet set in raspberry. Journal of Applied Ecology, 51, 1603-1612. https:// doi.org/10.1111/1365-2664.12325

Sampson, B. J., \& Cane, J. H. (2000). Pollination efficiencies of three bee (Hymenoptera: Apoidea) species visiting Rabbiteye Blueberry. Journal of Economic Entomology, 93(6), 1726-1731. https://doi. org/10.1603/0022-0493-93.6.1726

Sapir, G., Goldway, M., Shafir, S., \& Stern, R. A. (2007). Multiple introduction of honeybee colonies increases cross-pollination, fruit-set and yield of 'Black Diamond' Japanese plum (Prunus salicina Lindl.). The Journal of Horticultural Science and Biotechnology, 82, 590-596. https://doi.org/10.1080/14620316.2007.11512278

Seeley, T. D. (1985). Honeybee ecology: A study of adaptation in social life. Princeton, NJ: Princeton University Press.

Sheffield, C., Ngo, H. T., \& Azzu, N. (2016). A manual on apple pollination. Rome, Italy: FAO Food and Agriculture Organization of the United Nations.

Steffan-Dewenter, I. (2003). Seed set of male-sterile and male-fertile oilseed rape (Brassica napus) in relation to pollinator density. Apidologie, 34, 227-235. https://doi.org/10.1051/apido:2003015
Stern, R., Eisikowitch, D., \& Dag, A. (2001). Sequential introduction of honeybee colonies and doubling their density increases cross-pollination, fruit-set and yield in 'Red Delicious' apple. The Journal of Horticultural Science and Biotechnology, 76, 17-23. https://doi.org/10.1080/146203 16.2001.11511320

Stern, R. A., Goldway, M., Zisovich, A. H., Shafir, S., \& Dag, A. (2004). Sequential introduction of honeybee colonies increases crosspollination, fruit-set and yield of 'Spadona' pear (Pyrus communis L.). The Journal of Horticultural Science and Biotechnology, 79, 652-658. https://doi.org/10.1080/14620316.2004.11511821

Stern, R. A., Zisovich, A. H., Shafir, S., Dag, A., \& Goldway, M. (2005). Increasing the yield of 'spadona' pear (Pyrus communis L.) by appropriate utilization of beehives. Acta Horticultura Proceedings of the 9th International Pear Symposium, 671, 143-150.

Thom, C., Seeley, T. D., \& Tautz, J. (2000). A scientific note on the dynamics of labor devoted to nectar foraging in a honeybee colony: Number of foragers versus individual foraging activity. Apidologie, 31, 737-738. https://doi.org/10.1051/apido:2000158

Thorn, S., Bässler, C., Brandl, R., Burton, P. J., Cahall, R., Campbell, J. L., ... Müller, J. (2017). Impacts of salvage logging on biodiversity: A metaanalysis. Journal of Applied Ecology, 55, 279-289.

Tscharntke, T., Tylianakis, J. M., Rand, T. A., Didham, R. K., Fahrig, L., Batáry, P., ... Westphal, C. (2012). Landscape moderation of biodiversity patterns and processes - eight hypotheses. Biological Reviews, 87, 661685. https://doi.org/10.1111/j.1469-185X.2011.00216.x

Vaissiere, E. B. (1991). Honeybee stocking rate, pollinator visitation, and pollination effectiveness in upland cotton grown for hybrid seed production. Acta Horticulturae, 288, 359-363.

Vaissière, B., Freitas, B. M., \& Gemmill-Herren, B. (2011). Protocol to detect and assess pollination deficits in crops: A handbook for its use. Rome, Italy: FAO Food and Agriculture Organization of the United Nations.

Velthuis, H. H. W., \& van Doorn, A. (2006). A century of advances in bumblebee domestication and the economic and environmental aspects of its commercialization for pollination. Apidologie, 37, 31.

Walters, S. A. (2005). Honeybee pollination requirements for triploid watermelon. HortScience, 40, 1268-1270. https://doi.org/10.21273/ HORTSCI.40.5.1268

Walters, S. A., \& Taylor, B. H. (2006). Effects of honeybee pollination on pumpkin fruit and seed yield. HortScience, 41, 370-373. https://doi. org/10.21273/HORTSCI.41.2.370

Witter, S., Nunes-Silva, P., Lisboa, B. B., Tirelli, F. P., Sattler, A., Both Hilgert-Moreira, S., \& Blochtein, B. (2015). Stingless bees as alternative pollinators of canola. Journal of Economic Entomology, 108(3), 880-886. https://doi.org/10.1093/jee/tov096

Young, H. J. (1988). Differential importance of beetle species pollinating Dieffenbachia Longispatha (Araceae). Ecology, 69, 832-844. https:// doi.org/10.2307/1941033

Young, H. J., \& Young, T. P. (1992). Alternative outcomes of natural and experimental high pollen loads. Ecology, 73, 639-647. https://doi. org/10.2307/1940770

Zhang, H., Huang, J., Williams, P. H., Vaissière, B. E., Zhou, Z., Gai, Q., ... An, J. (2015). Managed bumblebees outperform honeybees in increasing peach fruit set in China: Different limiting processes with different pollinators. PLoS ONE, 10, e0121143.

How to cite this article: Rollin O, Garibaldi LA. Impacts of honeybee density on crop yield: A meta-analysis. J Appl Ecol. 2019;56:1152-1163. https://doi.org/10.1111/1365 2664.13355 